\title{
Stress and Strain Analysis of Plywood Seat Shell
}

\section{Analiza naprezanja i deformacije furnirskog otpreska sjedala}

\author{
Original scientific paper • Izvorni znanstveni rad \\ Received-prispjelo: 19. 6. 2018. \\ Accepted-prihvaćeno: 10. 12. 2018. \\ UDK: $630 * 812.794 ; 630 * 812.76 ; 630 * 832.282$ \\ doi: $10.5552 /$ drvind.2019.1825
}

\begin{abstract}
In this paper, the stress and strain analysis of common laminated wood seat shell is performed. Experimental stiffness evaluation is conducted by measuring displacement of the point on the backrest, and experimental stress analysis is carried out by tensometric measuring at the critical transition area from the seat to the backrest. Finite element analysis is carried out layer by layer with a " $2 D$ linear elastic model" for orthotropic materials. Good matching is found between numerical and experimental results of displacement. It is also shown that the results of the principal stress in the measurement points of the seat shell compare favourably with experimental data. The applied in-plane stress analysis of each individual veneer is not applicable for interlaminar stress calculations that are a significant factor in curved forms of laminated wood. Curved forms of laminated wood products require more complex numerical analysis, but the method can be used to achieve approximate data in early phase of product design.
\end{abstract}

Keywords: laminated wood, seat shell, tensometric measuring, strain gauges, stress, strain, FEM

SAŽETAK • U radu je provedena analiza naprezanja i deformacija uobičajenog otpreska sjedala. Eksperimentalna procjena krutosti napravljena je mjerenjem pomaka točke na naslonu sjedala, a eksperimentalna analiza naprezanja obavljena je tenzometrijskim mjerenjem na kritičnom prijelazu između sjedala i naslona. Analiza metodom konačnih elemenata provedena je sloj po sloj 2D linearnim elastičnim modelom za ortotropne materijale. Dobivena je dobra podudarnost računskih i eksperimentalnih rezultata pomaka. Također je potvrđeno da su rezultati glavnog naprezanja u mjernim točkama furnirskog otpreska sjedala usporedivi s eksperimentalnim podatcima. Odabrana analiza naprezanja u ravnini svakoga pojedinačnog furnira nije primjenjiva za izračun interlaminarnih naprezanja, koja su važan čimbenik zakrivljenog oblika uslojenog drva. Naime, takvi oblici uslojenog drva zahtijevaju složeniju računsku analizu, no metoda se može primijeniti za postizanje približnih podataka u ranoj fazi projektiranja proizvoda.

Ključne riječi: uslojeno drvo, otpresak sjedala, tenzometrija, davač pomaka, naprezanje, deformacija, FEM

\section{INTRODUCTION 1. UVOD}

Laminated wood composites, such as plywood and curved veneer products, have a wide range of application in furniture industry. Plywood shells are common and basic elements of a certain type of chair constructions. Today, there is a considerable interest in developing new complex forms of the seat shells due to rapid trend changes. A better understanding of specific mechanical and physical properties of laminated structure can lead to quality improvement of curved veneer products.

Laminated wood products have a balanced construction made of veneer sheets and their properties depend on properties of individual veneers, veneers layout and parameters of production process. Different fibre orientations, fibre deviations and moisture con-

\footnotetext{
${ }^{1}$ Authors are associate professors, assistant professor and PhD student at University of Sarajevo, Mechanical Engineering Faculty, Sarajevo, Bosnia and Herzegovina.

${ }^{1}$ Autori su izvanredni profesori, docent i doktorandica na Sveučilištu u Sarajevu, Strojarski fakultet, Sarajevo, Bosna i Hercegovina.
} 
tent variations before moulding have a clear impact on shape stability of the laminated veneer products both after moulding and during use (Blomqvist et al., 2013). Basic concepts of laminated wood analysis are based on knowledge of the elastic parameters of individual laminae and its composition (Boding, 1993). More extended analytic model can be found in studies of analytic evaluation of radial stress unfolding failure of composite materials (Gonzalez-Cantero et al., 2014). The possibility of applying computer programs for the evaluation of mechanical properties of laminated wood and choosing the optimal material for product development is demonstrated by Brezović et al. (2018). The results of experimental analysis of plywood tensile strength through a change of the position of layers in the panel structure around the central axis show that different veneer layouts in plywood structure have a remarkable impact on plywood tensile strength (Jakimovska Popovska, et al., 2017). Numerical methods, such as the 'finite element method', are applicable and effective for the analysis of laminated wood, and the numerical results depend on simplifications and assumptions introduced in the numerical model. Numerical determination of stresses and deformations developed during the veneer products manufacture show that heating, pressure and fibre orientation in the veneers have a noticeable influence on the distortion of the chair seat (Sandberg and Ormarsson, 2007). The numerical analysis of the effect of veneer composition on the mechanical properties of rectangular and curved form of laminated wood has been tested and the results show that curved forms require more complex analysis (Hajdarevic et al., 2017). Veneer properties are considered as design tool affecting the behaviour of laminated wood structure (Nestorović et al., 2011). Design possibilities for seat shells using linear elastic analysis have been explored by Vratuša et al. (2017).

The aim of this study was to determine stiffness and stress of the laminated wood complex structure obtained by numerical method and to compare the results of numerical calculation with test results in order to determine the effects of numerical method, assumptions and simplifications used in the numerical calculation of a structure stiffness and stress. The objective was to show the results that can be expected, depending on complex forms of structure and approach to structural design. In this study, experimental and numerical method (FEM) was used for the analysis of the stiffness and normal stress of the seat shells. The stiffness and stress distribution in the complex laminated wood construction used in this study was determined in order to explore and demonstrate capabilities of numerical calculation in design optimization.

\section{MATERIALS AND METHODS}

2. MATERIJALI I METODE

\subsection{Materials}

2.1. Materijali

The plywood seat shell taken from manufacturing process was analyzed (Figure 1). The seat, $B \times D \times$ $H=400 \mathrm{~mm} \times 442 \mathrm{~mm} \times 434.5 \mathrm{~mm}$, was made from eight plies of beech veneer. Urea-formaldehyde adhesive (UF) with catalyst ( $\mathrm{NH} 4 \mathrm{Cl}$ ) was used to bond veneers with a spread rate of $160 \mathrm{~g} / \mathrm{m}^{2}$. The veneers were oriented longitudinally, except the third and sixth layer, with transverse oriented veneers. The thickness of all veneers was $1.5 \mathrm{~mm}$, except the externals ones, whose thickness was $0.75 \mathrm{~mm}$. Mean value of plywood thickness was $10.5 \mathrm{~mm}$.

Loading diagram of seat shell is shown in Figure 2. The position of the concentrated force direction was defined by the distances $h=264.5 \mathrm{~mm}$ and $d=209$ $\mathrm{mm}$. The seat part of the shell was fixed in the zone of connection with pedestal. The load was applied to the backrest in a manner that corresponds to statically testing the backrest. The seat shell was loaded and unloaded five times on a universal testing machine. The maximum force $F=500 \mathrm{~N}$ was applied to the backrest across the curved shape metal plate. The displacement
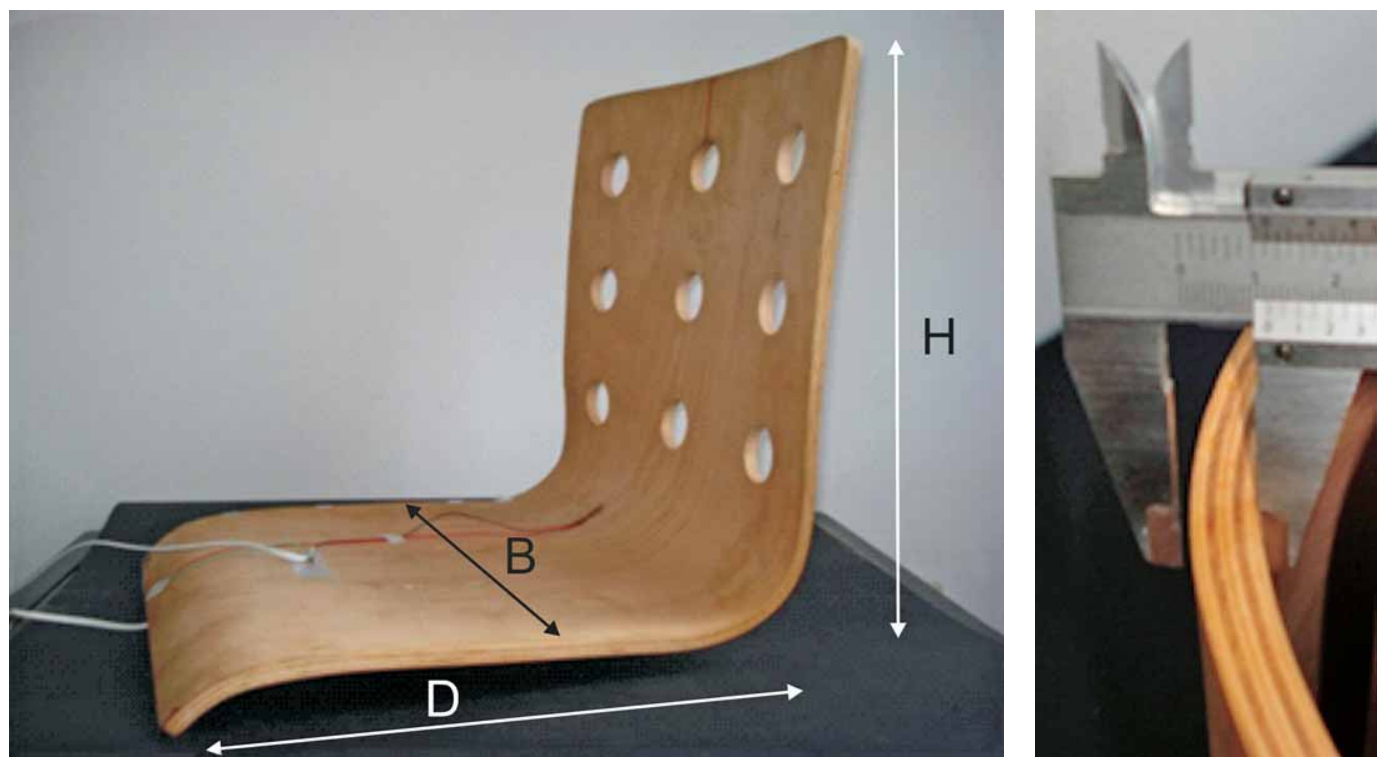

Figure 1 Shape of plywood seat shell (left) and orientation of plywood layers (right)

Slika 1. Oblik furnirskog otpreska sjedala (lijevo) i smjer protezanja slojeva furnirskog otpreska (desno) 

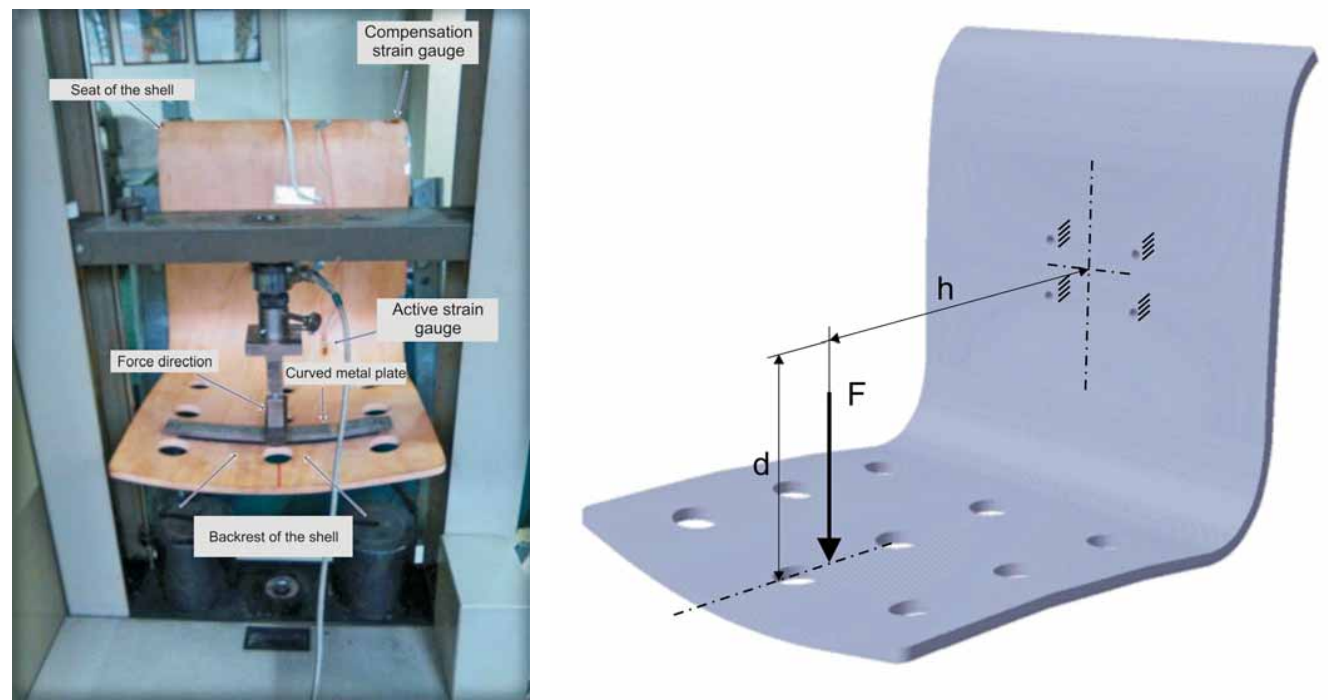

Figure 2 Testing of seat shell (left) and test static scheme (right)

Slika 2. Ispitivanje otpreska sjedala (lijevo) i statička shema ispitivanja (desno)

of the backrest point in the direction of the force $\mathrm{F}$ and stress in two critical points of the shell were measured during the testing.

Tensometric measurement equipment was used to monitor the value of the dominant principal stress in the critical transition area from the seat to the backrest. Four strain gauges (HMB type 6/120 LY11) connected in two Wheatstone quarter bridge were used. The active strain gauges were placed on the two opposite sides (faces and back) of the seat shell in the direction of the appearance of maximum and minimum principal stresses, i.e. fibre direction of external ply of beech veneer (Figure 3). Compensating strain gauges were placed near the edge of a seat shell in the no-strain zone and they were used to compensate the effect of temperature on the measurement. Two channels data acquisition system was used. Display and processing of measurement results were performed using the HBM Catman software.

Numerical model was solved by a method based on the finite element as a 2D problem with shell elements. Each layer was defined by a unique set of wooden material properties and orientation. Adhesive was neglected. Calculations were performed using the Catia software package (Figure 4).

Calculation was carried out for beech wood ( $\mathrm{Fa}$ gus sylvatica L.). The elastic properties of the wood used in calculations are presented in Table 1 (Smardze-

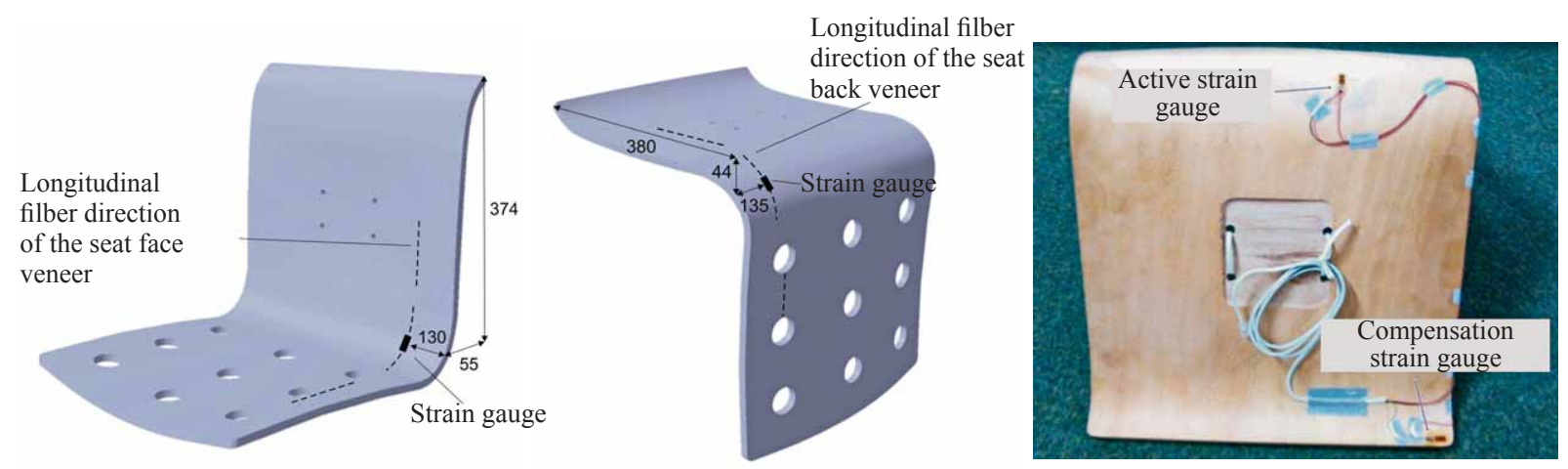

Figure 3 Position of active strain gauges (left), and position of active and compensating strain gauges at the back of the seat shell (right)

Slika 3. Položaj aktivnih davača pomaka (lijevo) i položaj aktivnih i kompenzacijskih davača pomaka na stražnjoj strani otpreska sjedala (desno)
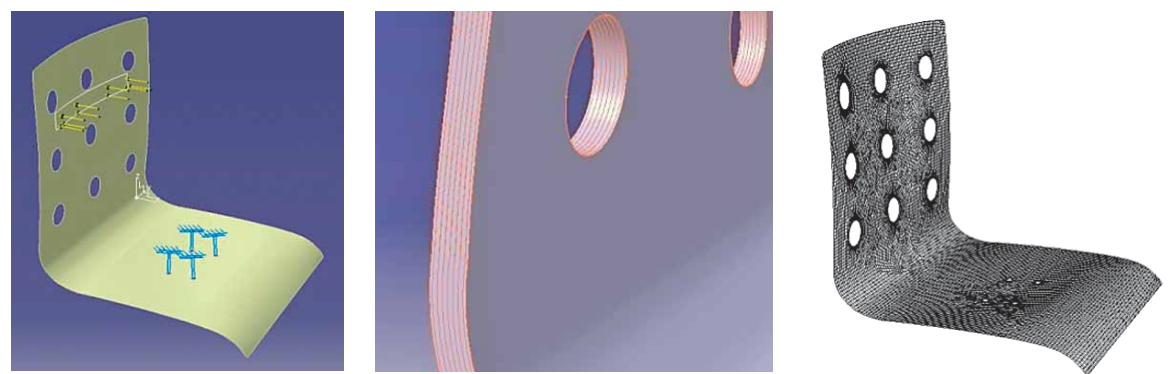

Figure 4 Numerical model: boundary conditions (left), layers (middle) and mesh (right)

Slika 4. Računski model: granični uvjeti (lijevo), slojevi (sredina) i mreža (desno) 
Table 1 Elastic properties of beech wood (Fagus sylvatica L.), $\rho=0.75 \mathrm{~g} / \mathrm{cm}^{3}$ (Smardzewski, 2008)

Tablica 1. Elastična svojstva bukovine (Fagus sylvatica L.), $\rho=0,75 \mathrm{~g} / \mathrm{cm}^{3}$ (Smardzewski, 2008.)

\begin{tabular}{|c|c|c|c|c|c|c|c|c|c|c|c|}
\hline \multicolumn{3}{|c|}{$\begin{array}{c}\text { Modulus of elasticity, } \mathrm{GPa} \\
\text { Modul elastičnosti, } \mathrm{GPa}\end{array}$} & \multicolumn{3}{|c|}{$\begin{array}{c}\text { Rigidity modulus, } \mathrm{GPa} \\
\text { Modul loma, } \mathrm{GPa}\end{array}$} & \multicolumn{5}{c|}{ Poisson's ratio } \\
\hline$E_{\mathrm{L}}$ & $E_{\mathrm{R}}$ & $E_{\mathrm{T}}$ & $G_{\mathrm{LR}}$ & $G_{\mathrm{LT}}$ & $G_{\mathrm{RT}}$ & $v_{\mathrm{LR}}$ & $v_{\mathrm{LT}}$ & $v_{\mathrm{RT}}$ & $v_{\mathrm{TR}}$ & $v_{\mathrm{RL}}$ & $v_{\mathrm{TL}}$ \\
\hline 13.969 & 2.284 & 1.160 & 1.645 & 1.082 & 0.471 & 0.450 & 0.510 & 0.750 & 0.360 & 0.075 & 0.044 \\
\hline
\end{tabular}

wski, 2008). Appropriate elastic properties for analysis in the LT plane were selected.

\section{RESULTS AND DISCUSSION 3. REZULTATI I RASPRAVA}

The experimental result of displacement of the backrest point in the direction of the force $\mathrm{F}$ is shown in Figure 5. The data obtained from test were used in a regression analysis. The linear regression model for the data was well fitted and the results of this analysis are shown in Figure 5. A proportional relationship between the displacement and the force for the load level up to
$500 \mathrm{~N}$ was found. The load was below the limit of proportionality and only elastic deformation appeared.

The results of the numerical calculation comprising displacement of the backrest point in the direction of the force $\mathrm{F}$ is shown in Figure 6. The seat shell was loaded with a force of $300 \mathrm{~N}$, i.e. the approximate value used to test the maximum distance of displacement of the backrest of some types of chairs.

The numerical result of displacement of the backrest point in the direction of the force $F=300 \mathrm{~N}$ was $17.8 \mathrm{~mm}$, while the experimentally obtained result, i.e. obtained by regression analysis was $20.1 \mathrm{~mm}$. Percentage difference between values of displacement ob-

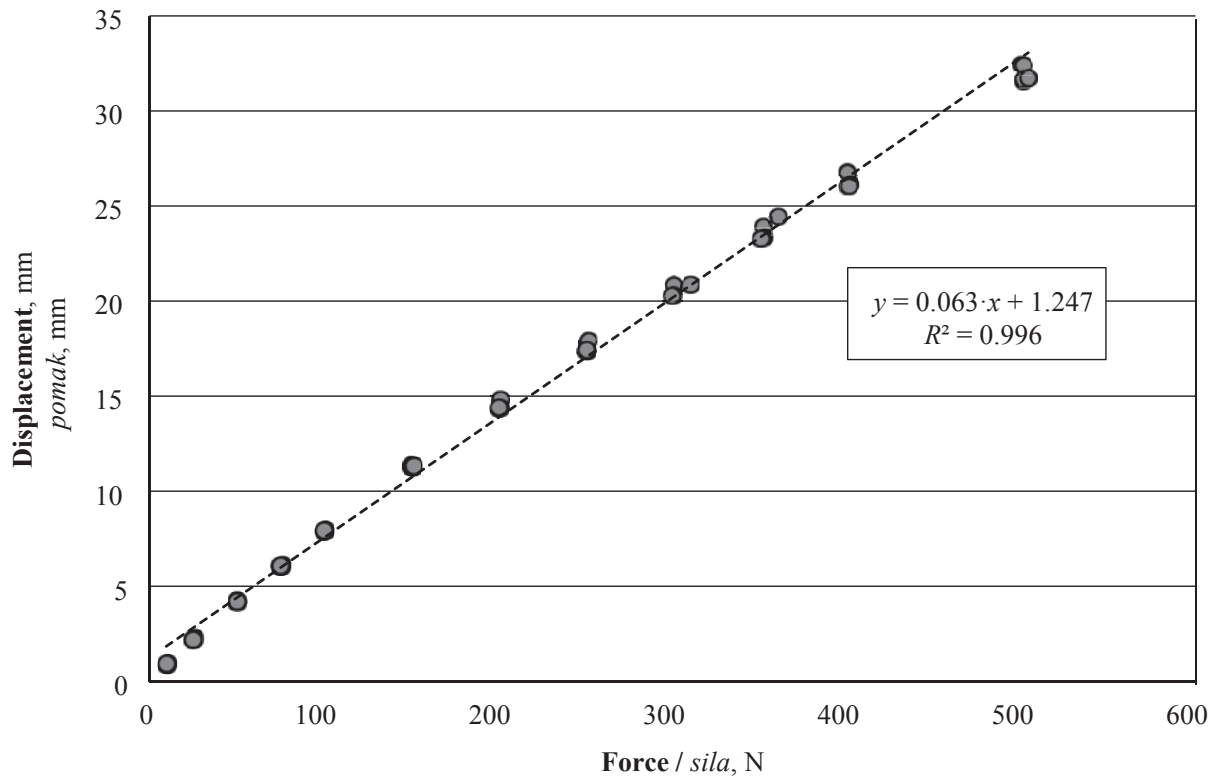

Figure 5 Experimental result of displacement of the backrest point in the direction of force $\mathrm{F}$ Slika 5. Eksperimentalni rezultati pomaka točke naslona u smjeru sile $F$
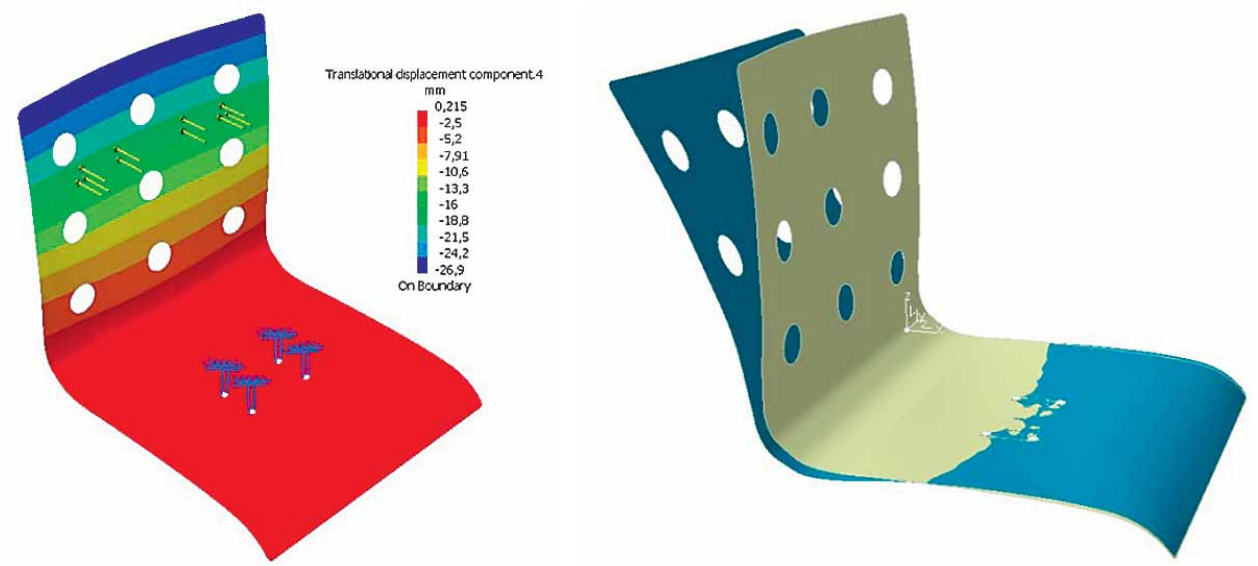

Figure 6 Numerical result of strain analysis: distribution of translational displacement component in the direction of force $F$ (left), deformation of seat shells (right)

Slika 6. Računski rezultati analize deformacije: raspodjela pomaka u smjeru sile $F$ (lijevo), deformacije otpreska sjedala (desno) 


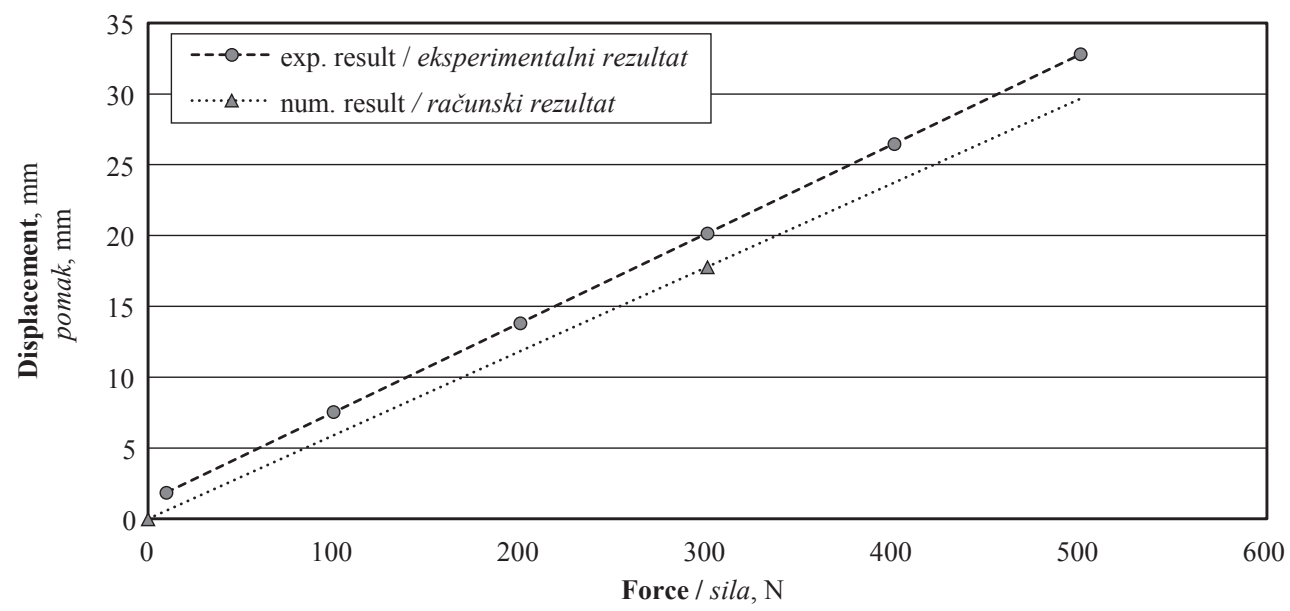

Figure 7 Experimental and numerical results of displacement of the backrest point in the direction of the force $\mathrm{F}$ Slika 7. Eksperimentalni i računski rezultati pomaka točke naslona u smjeru sile F

tained experimentally and from numerical calculation is $12.13 \%$. The numerical result showed smaller displacement of the point, i.e. higher rigidity of the structure than the displacement measured in the testing (Figure 7).

The change of relative deformations recorded by strain gauges, placed on the face and back of the seat shell during load application, is shown in Figure 8. The relative deformation at the seat face was positive (fibres were subjected to tension), while the relative deformation at the seat back was negative (fibres were subjected to pressure). The curves are not symmetrical i.e. the absolute values of deformation at the two measuring points were not the same. Unexpected decrease of deformations occurred in $\sim 500$ seconds of the test due to the sudden slipping of the backrest under the curved shape metal plate at the load greater than $500 \mathrm{~N}$.

The experimental result of relative deformation in the function of the force $\mathrm{F}$ at the two measuring points of the critical transition area is shown in Figure 9. A regression analysis was applied to the data obtained by testing and a proportional relationship be- tween the relative deformation and the force for the load level up to $500 \mathrm{~N}$ was determined.

The relative deformations at the measuring points measured by the strain gauges are the dominant principal strains ( $\varepsilon_{1}$ at the seat face and $\varepsilon_{3}$ at the seat back). The directions of dominant principal strains coincided with longitudinal direction of outer wood veneers. The dominant principal stresses at the measuring points $\left(\sigma_{1}\right.$ at the seat face and $\sigma_{3}$ at the seat back) are determined by the Hooke's law:

$$
\sigma_{1}=E_{\mathrm{L}} \cdot \varepsilon_{1} \text { and } \sigma_{3}=E_{\mathrm{L}} \cdot \varepsilon_{3}
$$

Where the index 1 and 3 denote the extreme values in a spatial analysis, and $E_{\mathrm{L}}(\mathrm{Pa})$ is longitudinal modulus of elasticity of beech wood (Table 1).

The experimental results of normal stress (principal stress) in the function of the force $F$ at the two measuring points of the critical transition area are shown in Figure 10. The proportional relationship between the normal stress and the force for the load level up to $500 \mathrm{~N}$ shows that the tensile stress at the seat face is greater than compressive stress at the symmetrical seat back.

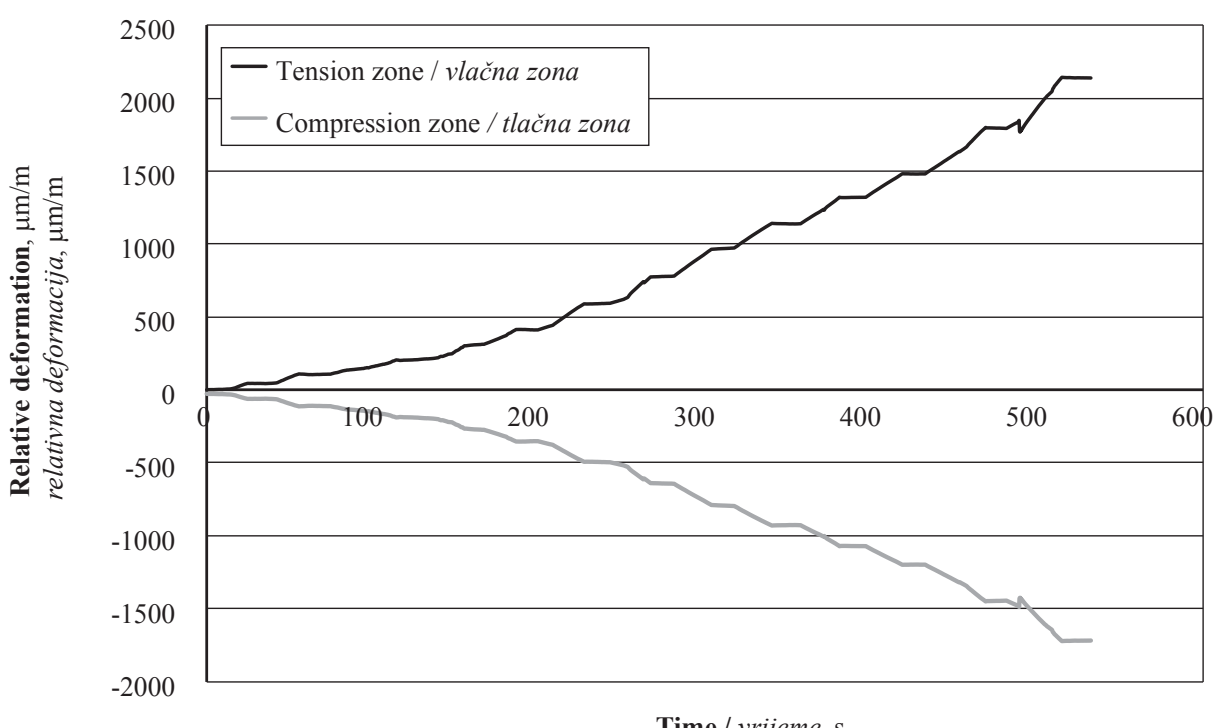

Time / vrijeme, $\mathrm{s}$

Figure 8 Change of relative deformation recorded by strain gauges placed on the face and back of the seat shell

Slika 8. Promjene relativne deformacije zabilježene davačima pomaka postavljenima na licu i naličju otpreska sjedala 
Hajdarević, Obućina, Mešić, Martinović: Stress and Strain Analysis of Plywood Seat Shell ...

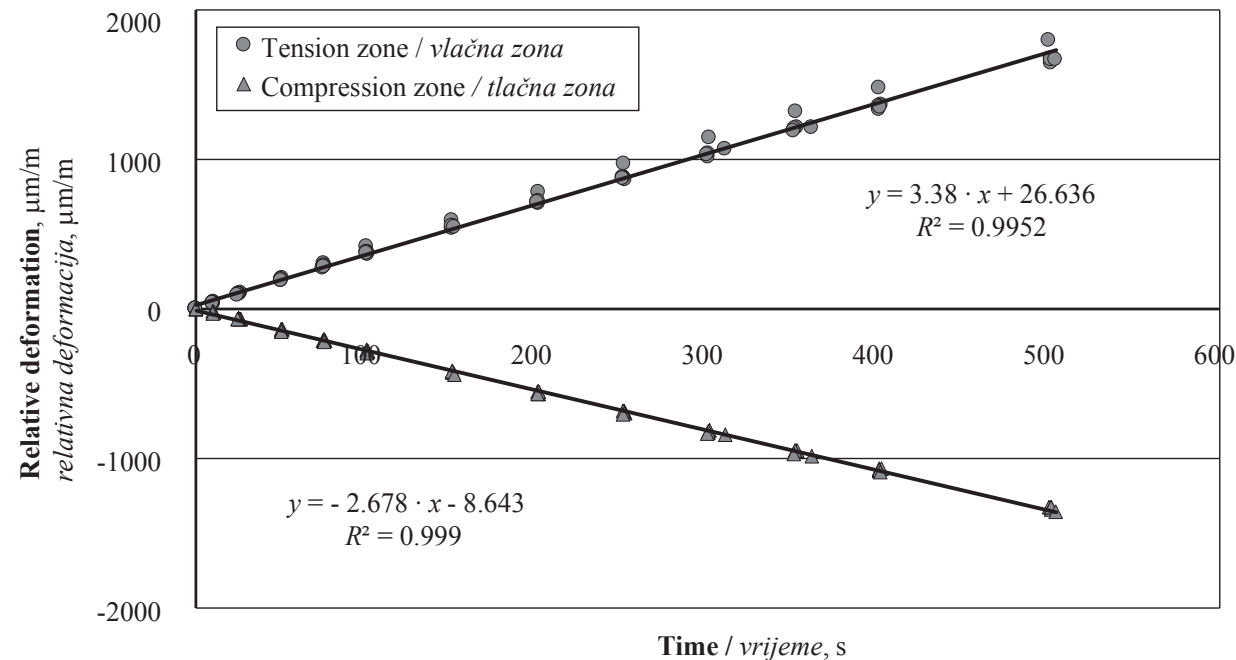

Figure 9 Experimental result of relative deformation in the function of force $\mathrm{F}$ at two measuring points Slika 9. Eksperimentalni rezultati relativne deformacije u odnosu prema sili za dvije mjerne točke

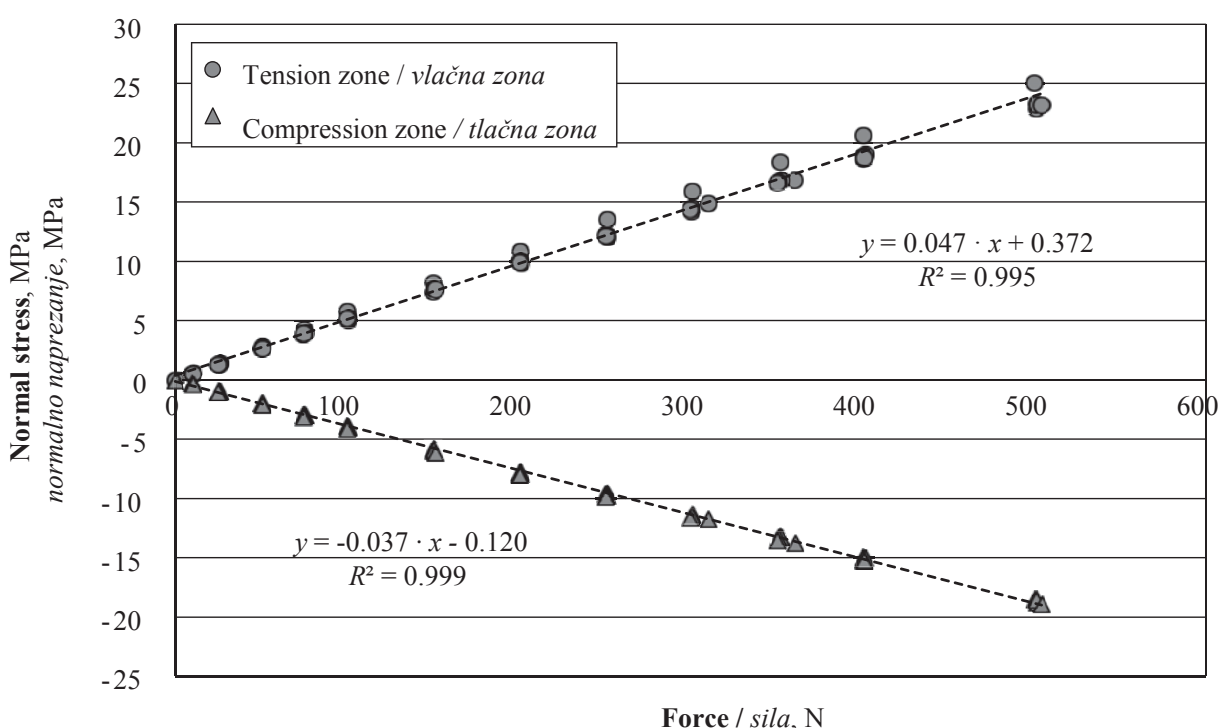

Figure 10 Experimental results of normal stress in the function of force $F$ at two measuring points Slika 10. Eksperimentalni rezultati normalnog naprezanja u odnosu prema sili za dvije mjerne točke
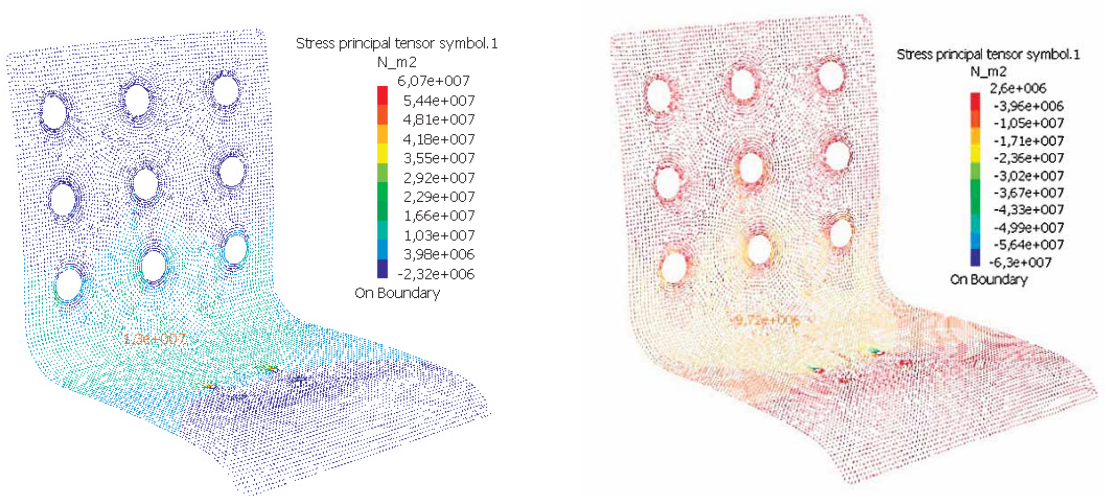

Figure 11 Numerical results of normal stress (in-plane principal stress): distribution of $\sigma_{1}$ in external veneer ply at the seat face (left), distribution of $\sigma_{2}$ in external veneer ply at the seat back (right)

Slika 11. Računski rezultati normalnog naprezanja (u ravnini glavnog naprezanja): raspodjela $\sigma_{1}$ u vanjskom sloju furnirskog otpreska na prednjoj strani sjedala (lijevo), raspodjela $\sigma_{2}$ u vanjskom sloju furnirskog otpreska na stražnjoj strani sjedala (desno) 


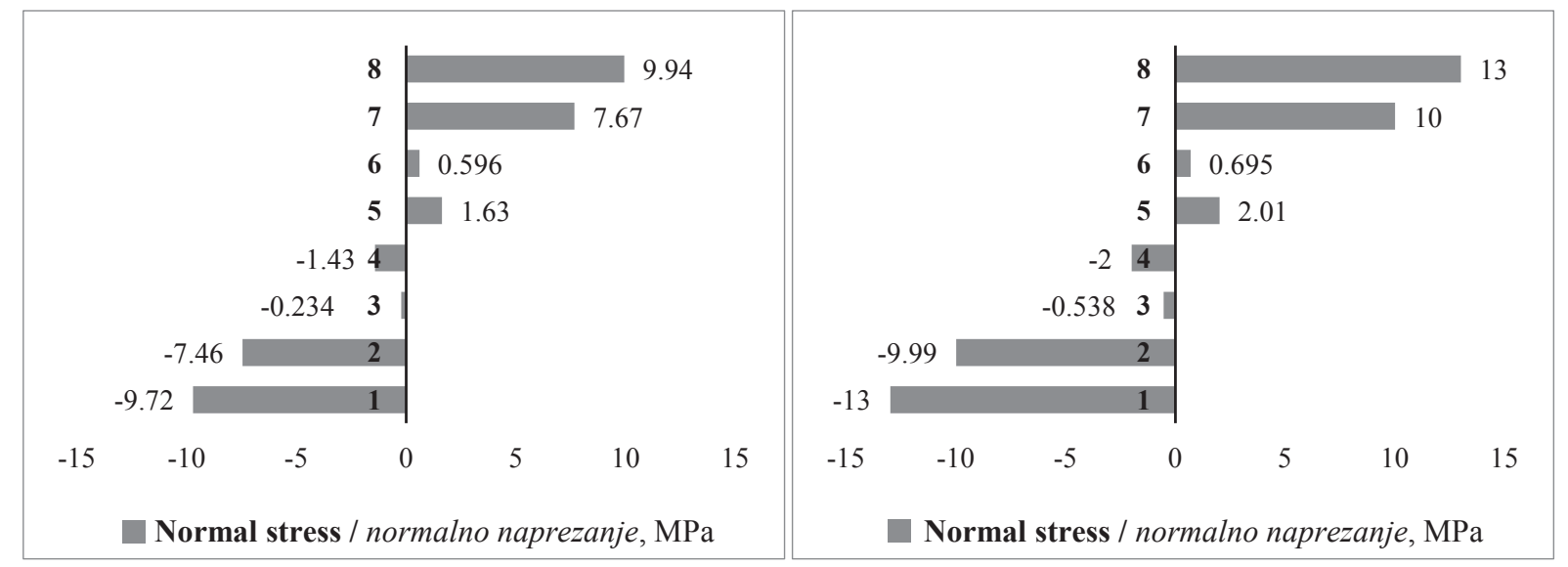

Figure 12 Numerical results of normal stress (principal stress) at half thickness of 8 veneer sheets: the point measured by strain gauges at the seat face (left), point measured by strain gauges at the seat back (right)

Slika 12. Računski rezultati normalnog naprezanja (glavno naprezanje) na pola debljine otpreska od osam listova furnira: mjereno davačima pomaka na prednjoj strani sjedala (lijevo) i na stražnjoj strani sjedala (desno)

The experimental results of normal stress (principal stress), obtained by regression analysis, at points in the critical transition area for the force $F=300 \mathrm{~N}$ were 14.53 $\mathrm{MPa}$ at the seat face and $-11.34 \mathrm{MPa}$ at the seat back. Distributions of the normal stress (principal stress $\sigma_{1}$ and $\sigma_{2}$ obtained by in-plane analysis) in the two external veneer plies and for the same force intensity obtained by numerical calculation are shown in Fig. 11. When using orthotropic elasticity and to describe the stress and strain state in individual veneer plies of a seat shell, a plane stress system was introduced. The normal and shear stress were recognized only in a veneer plane. The numerical results of normal stress (principal stress $\sigma_{1}$ at the seat face and $\sigma_{2}$ at the seat back) at the points of the critical transition area were $13 \mathrm{MPa}$ at the half thickness of the seat face veneer and $-9.72 \mathrm{MPa}$ at the half thickness of the seat back veneer.
The numerical results of normal stress at the cross section of the half thickness of 8 veneers in seat face and seat back zones are shown in Figure 12.

The numerical results show that the tensile stress was greater than compressive stress at the cross-section and that longitudinally oriented veneers sustained higher stress than veneers with tangential orientation. The neutral axis and the centroidal axis of the crosssection were not coincident, and also the stress did not vary linearly from the neutral axis. An approximate linear estimate of the normal stress on the outer surfaces and at the two measuring points was $14 \mathrm{MPa}$ at the point of the seat face veneers and $-10.46 \mathrm{MPa}$ at the point of the seat back veneers. Percentage difference between values of normal stress for the force $F=300$ $\mathrm{N}$ obtained numerically and experimentally was 3.76 $\%$ for the point at the seat face and $8.07 \%$ for the point at the seat back (Figure 13).

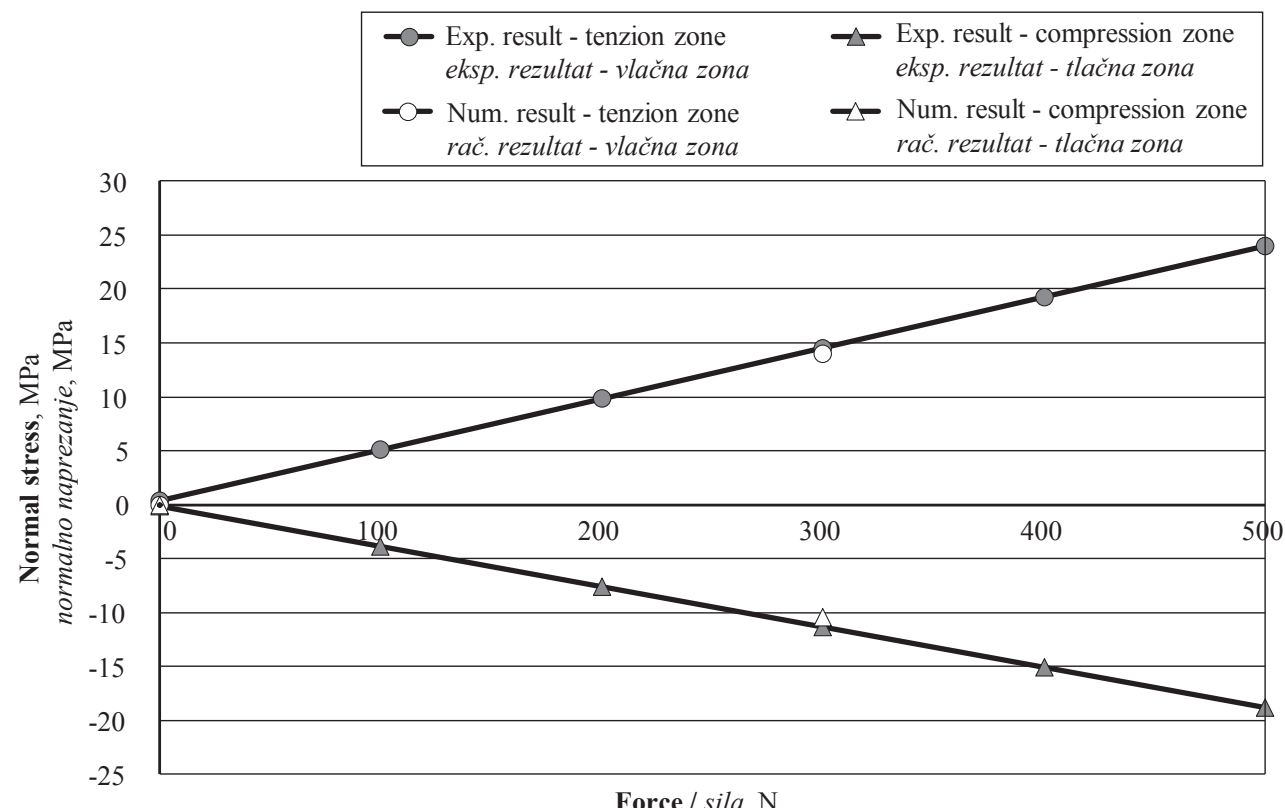

Figure 13 Experimental (Exp.) and numerical (Num.) results of normal stress at two measuring points of critical transition area (tension zone - the seat face and compression zone - the seat back)

Slika 13. Eksperimentalni (eksp.) i računski ( $r a c ̌$.) rezultati normalnog naprezanja za dvije mjerne točke u kritičnom prijelaznom području (vlačna zona - prednja strana sjedala i tlačna zona - stražnja strana sjedala) 


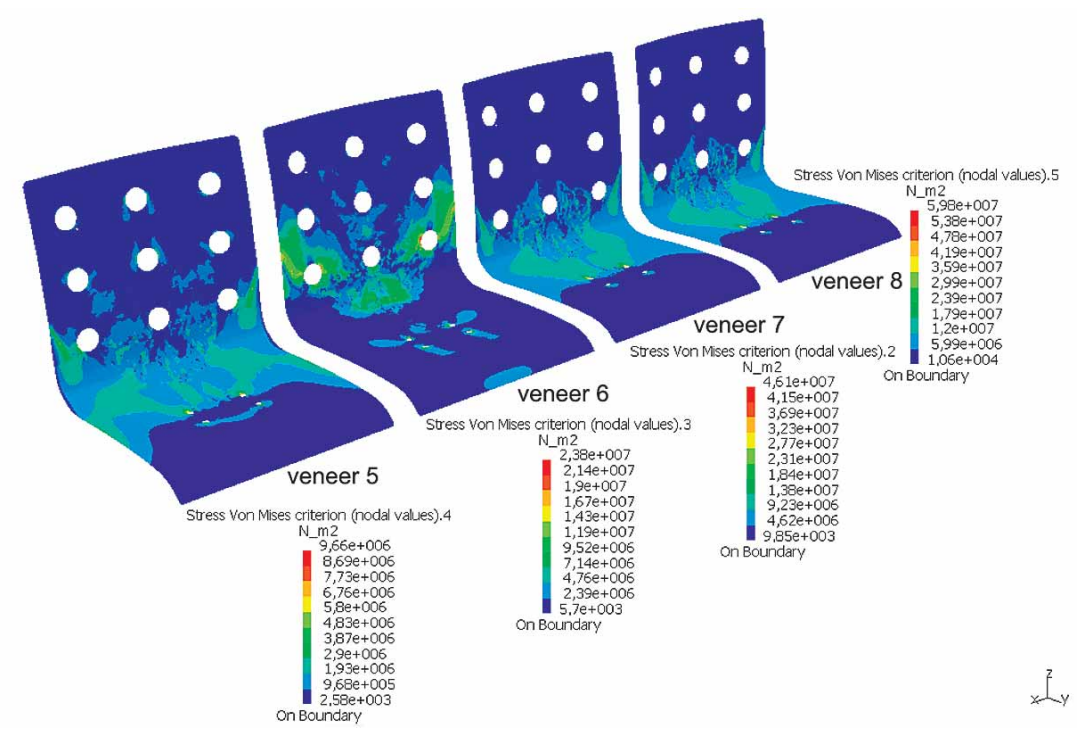

Figure 14 Distribution of Von Mises stress - tension zone (veneers 5, 6, 7 and 8)

Slika 14. Raspodjela Von Misesova naprezanja - vlačna zona (furniri 5., 6., 7. i 8.)

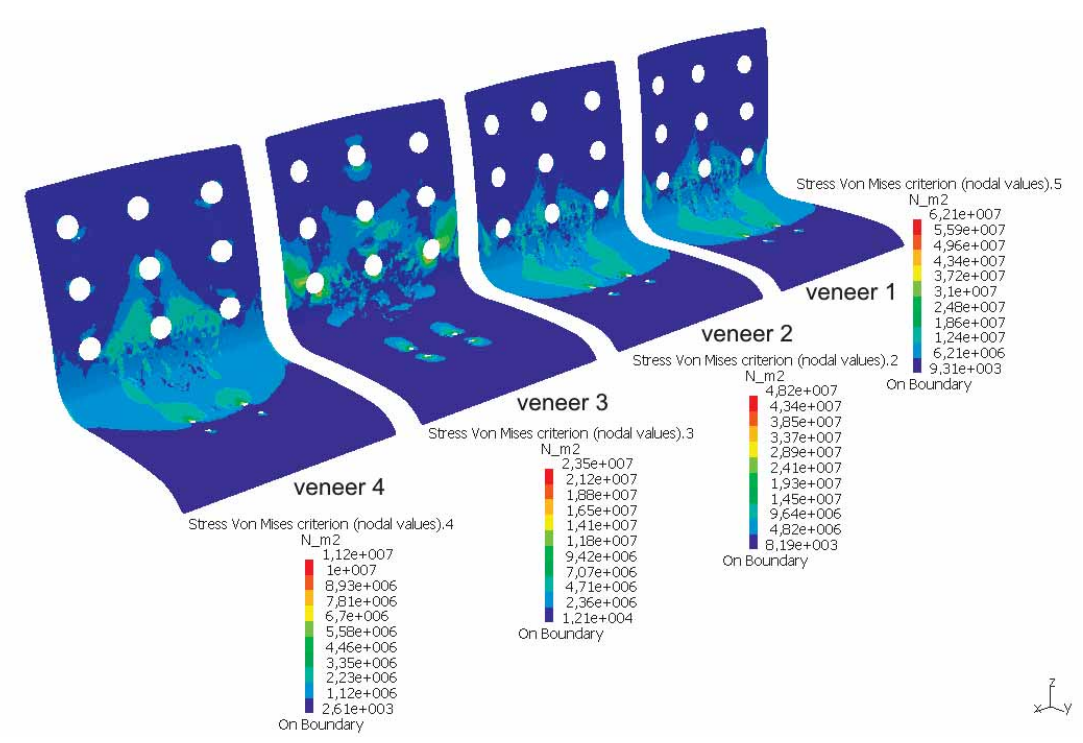

Figure 15 Distribution of Von Mises stress - compression zone (veneers 4, 3, 2 and 1)

Slika 15. Raspodjela Von Misesova naprezanja - tlačna zona (furniri 4., 3., 2. i 1.)

The distribution of the Von Mises stress in the plane of all the eight veneers is shown in Figure 14 and 15. The Von Mises stress, commonly used approximation that assumes that the material is isotropic, can be a sufficiently good indicator of the stress state of the loaded construction made of orthotropic material. The maximum and increased values of this stress occurred in the fixing zone, critical transition area from the seat to the backrest and around the lower row of circular holes on the backrest. Veneers (3 and 6), tangentially oriented, had a different stress distribution and sustained smaller stress than veneers with longitudinal orientation.

The applied in-plane stress analysis revealed the circumferential (normal) stress in the curved areas of the seat shell. The analysis is not capable to calculate the radial (interlaminar) stresses. Radial stress is usually smaller than the circumferential stress and is low where the circumferential stresses are large (Young,
2001). It is not a major subject of consideration in compact material but it is a remarkable factor and the main cause of failure in curved forms of laminated wood. A radial stress that is larger than tensile strength perpendicular to fibres in a laminated wood leads to veneer delamination i.e. its separation into layers. The numerical analysis should be extended to calculate the radial (interlaminar) stresses on the real laminated veneer product.

\section{CONCLUSIONS 4. ZAKLJUČAK}

Similarity between numerical and experimental results of stress and strain analysis of the plywood seat shell allows the conclusion that the research models were designed correctly. The experimental results show proportional, linear relationship between the applied force (up to $500 \mathrm{~N}$ ) and displacement and applied 
force and stress that occurred in the observed points. Good matching was found between the numerical and experimental results of displacement at the backrest point, as well as between the numerical results and results of the tensometric analysis of the principal stress in the points at the critical transition area of the seat shell. The research revealed that the numerical procedure used in the study provides a convenient method of obtaining the information needed for determining the basic mechanical properties of laminated wood of complex shape. The applied in-plane stress analysis of each individual veneer is not capable of calculating the radial (interlaminar) stresses that are a remarkable factor and the main cause of failure in curved forms of laminated wood. Curved forms require more complex analysis. The results of numerical simulation of the loaded seat shell show that the numerical procedure can be successfully used to achieve approximate data in early design phase and development of laminated wood of any complex shape in order to reduce time and costs significantly.

\section{REFERENCES}

\section{LITERATURA}

1. Blomqvist, L.; Johansson, J.; Sandberg, D., 2013: Basic knowledge of wood properties for improved performance of laminate veneer products. Pro Ligno, 9 (4): 549-556.

2. Boding, J. B.; Jayne, A., 1993: Mechanics of wood and wood composites, Krieger publishing Company, Malabar Florida.

3. Brezović, M.; Pervan, S.; Petrak, J.; Prekrat, S., 2018: Metoda procjene svojstava uslojenog drva. Drvna industrija, 69 (1): 49-54.

https://doi.org/10.5552/drind.2018.1738.

4. Gonzalez-Cantero, J. M.; Graciani, E.; Blazquez, F.; Paris, F., 2014: Analytic evaluation of radial stress in unfolding failure of composite materials Comparison with numerical solution. In: Proceedings of 16th European conference on composite materials, Seville, Spain, June $22-26$.
5. Hajdarevic, S; Obucina, M.; Mesic, E., 2017: Effect of Veneer Composition on the Stiffness and Stress of Laminated Wood. In: Proceedings of the 28th DAAAM International Symposium, Zadar, Croatia, November 18-11, pp. 0341- 0350 .

6. https://dx.doi.org/10.2507/28th.daaam.proceedings.047.

7. Jakimovska Popovska, V.; Iliev, B.; Zlateski, G., 2017: Impact of veneer Layouts on Plywood Tensile Strength. Drvna industrija, 68 (2): 153-161.

https://doi.org/10.5552/drind.2017.1634.

8. Nestorović, B.; Skakić, D.; Grbac, I., 2011; Determining the Characteristics of Composite Structure Laminae by Optical 3D Measurement of Deformation with Numerical Analysis. Drvna industrija, 62 (3): 193-200. https://doi.org/10.5552/drind.2011.1103.

9. Sandberg, D.; Ormarsson, S., 2007: Numerical simulation of hot-pressed veneer products, working paper no. 2007:19, Vaxjo University, School of Technology \& Design, Sweden.

10. Smardzewski, J., 2008: Effect of wood species and glue type on contact stresses in a mortise and tenon joint. Journal of Mechanical Engineering Science, 222 (12): 2293-2299. https://doi.org/10.1243/09544062JMES1084.

11. Vratuša, S.; Kariž, M.; Ayrilmis, N.; Kitek Kuzman, M., 2017: Finite element simulations of the loading and deformation of plywood seat shells. European Journal of Wood and Wood Products, 75 (5): 729-738. https://doi.org/10.1007/s00107-017-1160-4.

12. Young, W. C.; Budynas, R. G., 2001: Roark's Formulas for Stress and Strain. McGraw-Hill Professional, ISBN 0-07-072542-X.

\section{Corresponding address:}

Assoc. Prof. SEID HAJDAREVIĆ, Ph.D.

University of Sarajevo, Mechanical Engineering Faculty Department of Wood Technology

Vilsonovo šetalište 9

BiH-71000 Sarajevo, BOSNIA AND HERZEGOVINA

e-mail: hajdarevic@mef.unsa.ba 